\title{
ОРГАНИЗАЦИОННО-ПРАВОВЫЕ ОСНОВЫ ДЕЯТЕЛЬНОСТИ АДВОКАТА ПО ЗАЩИТЕ ПРАВ ДОВЕРИТЕЛЯ В НАЛОГОВЫХ СПОРАХ
}

\author{
(C) 2021 Лошкарев А. В. \\ кандидат юридических наук \\ Самарский государственный экономический университет, Россия, Самара \\ E-mail:2482337@mail.ru \\ (c) 2021 Кашина А.B. \\ магистрант \\ Самарский государственный экономический университет, Россия, Самара \\ E-mail: kashin.anelu@mail.ru
}

Для формирования правового государства требуется постоянное реформирование российского законодательства, а также пересмотр значения социальных ценностей и основополагающих правовых институтов. Прежде всего, обновление законодательства направлено на демократизацию судопроизводства, так как в юридической сфере уже давно определили проблему существующего конфликта интересов между органами власти и гражданами при разрешении различного рода споров. Так, и налоговые споры являются камнем преткновения между налоговыми органами и налогоплательщиками.

Ключевые слова: адвокат, налоговый спор, судебный процесс, доверитель, закон, фискальные органы, справедливость, представительство в суде.

Налоговые споры отличаются от иных видов судебных споров тем, что с одной стороны интересы государства представляют налоговые органы в лице профессиональных юристов, а с другой стороны налогоплательщик защищает противоположные интересы. Мы сталкиваемся с проблемой, когда налогоплательщик не обладает достаточной квалификацией для защиты своих прав, и весь судебный процесс основывается исключительно на позиции налогового органа. Для таких случаев и предусмотрен адвокат, представляющий интересы доверителя в налоговых спорах.

Деятельность адвокатов по защите прав и интересов налогоплательщиков, в лице граждан и организаций, регламентируется законодательными нормами, определяющими процессуальные правомочия адвокатов, регулирующими их труд и организацию адвокатуры [1]. Адвокат является основным участником общественных отношений со стороны своего доверителя, через поведение которых достигаются результаты, которые намерен достигнуть законодатель, издавая нормы права. Регулирование взаимоотношений в обществе осуществляется при помощи законов (норм права).

Понятие «адвокатура» неотделимо от понятия «справедливость». На обыденном уровне категория «справедливость» очевидна и ясна всем.
Однако представление о справедливости как в обществе, так у отдельного гражданина может меняться. Это в значительной степени связано с теми или иными общественными идеалами. Сегодня, послесоветского исторического периода в жизни нашей страны, мы связываем свои представления с гуманистическими общечеловеческими ценностями, с представлениями о естественных и неотъемлемых правах и свободах человека и гражданина [2]. Возможность достижения справедливости в государстве является ценнейшим завоеванием демократии.

Так, налоговые органы зачастую ошибаются при начислении налога, необоснованно привлекают налогоплательщиков к ответственности, представляют необоснованные выводы проверки и допускают иные ошибки. Предметом спора в данном случае являются либо права, указанные в ст. 21 НК РФ [3], либо обязанности, указанные в п. 1 ст. 23 НК РФ, если инициатором являются налоговые органы. Налоговый спор обладает следующими признаками, определяющими необходимость участия профессионального субъекта, а именно адвоката, при представлении интересов доверителя, налогоплательщика:

1) Определенный законодательно состав субъектов. В налоговом споре с одной стороны участвуют государственные службы (налоговые), с другой - плательщики налогов (физические и 
юридические лица).

2) Характер спорного правоотношения. Налоговым считается только такое судебное разбирательство, которое следует из налогового законодательства РФ.

3) Фактическое неравенство сторон. Фискальные органы представляют собой государственную структуру. В свою очередь, состязательность и равенство сторон в процессе есть равноправие гражданина и государства, их паритет и равные возможности в отстаивании своих прав и интересов. А принимая во внимание, что интересы гражданина, как правило, представляет адвокат, то очевидно, что это означает равенство адвоката и государства. Равенство государства и адвокатуры, а также независимость последней являются важными условиями существования адвокатуры как защитника прав и свобод человека и гражданина.

4) Регламентированное законом ведение налоговых дел. Конфликт разрешается строго в прописанных законом формах, которые включают досудебное и судебное урегулирование.

Разрешение таких споров требует тщательной подготовки, опыта юридической практики в разрешении налоговых споров. Однако, физические лица, не обладающие юридическим образованием, зачастую не могут защитить свои права, а юридические лица не всегда располагают хорошим юридическим отделом, в частности, налоговыми юристами, которые смогут разрешить налоговый спор в пользу организации. В данном случае необходима квалифицированная помощь адвоката по налоговым спорам. Квалифицированная помощь подразумевает профессиональную юридическую помощь, которую адвокаты могут оказать, представительствуя в суде и иных государственных и общественных органах, осуществляя защиту в суде, проводя консультации и составляя правовые документы. Его помощь может затрагивать различные сферы общественной жизни, регулируемые отдельными институтами и отраслями права [4].

Так, задача адвоката по налоговым спорам заключается в подготовке претензий, оформлении документов, ведение дела в суде. Он берет на себя все обязательства по досудебному и судебному урегулированию. Также он может выступить уполномоченным представителем, сберегая время руководителя фирмы.

В целом можно обозначить основные моменты, определяющие объем работы адвоката с доверителем, налогоплательщиком, по налого- вым спорам [5].

Во-первых, адвокат должен обязательно провести консультацию с доверителем. Он должен понять суть налогового спора, а также перспективы его успешного разрешения, так как бывают ситуации, когда налогоплательщик ошибочно понимает сложившуюся ситуацию и не видит своего нарушения налогового законодательства. Поэтому адвокат возьмет данное дело только тогда, когда убедится, что есть реальная возможность выиграть налоговый спор.

Во-вторых, адвокат должен подготовить возражения на акт налоговой проверки в установленный законом срок. Уже на этом этапе необходимы квалифицированные знания налогового законодательства.

В-третьих, адвокат по налоговым спорам должен сформировать доказательственную базу. Прежде всего, это сведения о нарушениях в действиях налоговых инспекторов, которые подкреплены ссылками на законодательные акты. Также адвокат должен выявить процедурные нарушения, допущенные налоговым органом при проведении налоговой проверки, экспертизы, выемки, и иных действий.

В-четвертых, это составление жалобы на действия налоговых инспекторов, которая подается вышестоящему налоговому органу. Так как ФНС России старается сократить количество судебных дел по налоговым спорам, все жалобы, полученные в ходе досудебного производства изучаются данным контролирующим органом крайне скрупулезно. Поэтому от качества составленной жалобы зависит дальнейший исход дела.

Если же данная жалоба не будет разрешена ФНС России в пользу налогоплательщика, адвокат представляет интересы доверителя в суде на основании доверенности.

Также адвокат оказывает помощь доверителю в разблокировке счетов при положительном исходе судебного дела.

В настоящее время адвокатура является институтом гражданского общества, так как она обладает многими признаками и принципами гражданского общества, в частности: независимостью от государства, равноправием, защитой интересов, прав и свобод граждан [6]. Публичный характер адвокатуры вытекает непосредственно из ее профессиональной деятельности по защите прав и свобод граждан, а также из функций адвокатуры, которые важны для всего общества. 


\section{Библиографический список}

1. Федеральный закон от 31 мая 2002 г. № 63-Ф3 «Об адвокатской деятельности и адвокатуре в Российской Федерации» // Собрание законодательства Российской Федерации. 2002. № 23. Ст. 2102.

2. Беньяминова 3.Я. Адвокатура как институт гражданского общества: историко-правовой экскурс // Ученые труды Российской академии адвокатуры и нотариата. 2014. № 4. С. 9-11.

3. Налоговый кодекс Российской Федерации от 31 июля 1998 г. № 146-Ф3 // Собрание законодательства Российской Федерации. 1998. № 31. Ст. 3824.

4. Шокотько М.А. Особенности развития института адвокатуры в системе институтов гражданского общества: историко-правовой экскурс // Экономика и право. XXI век. 2017. № 2. С. 171-173.

5. учерена А.Г. Роль адвокатуры в становлении гражданского общества в России. Учебник. М.,2003. С.200.

6. Жамбалова Б.Б. Адвокатура как современный правовой институт гражданского общества // Молодой ученый. 2016. № 11 (115). С. 1289-1292. 